DOI: https://doi.org/10.24144/2409-6857.2020.2(56).70-80

УДК 332.14

\author{
Джигора О.М.
}

\title{
СУЧАСНІ ВИКЛИКИ ТА ЗАГРОЗИ РЕГІОНАЛЬНОГО РОЗВИТКУ, НАПРЯМИ ЇХ ПОДОЛАННЯ
}

\begin{abstract}
Стаття присвячена дослідженню викликів, основних загроз розвитку регіонів та ключових напрямів їх подолання. Досліджено сильні та слабкі сторони, можливості та загрози регіонів за допомогою SWOTаналізу. Визначено взаємозв'язки елементів SWOT-матриці регіонального розвитку та варіанти кореляцій між внутрішніми чинниками та зовнішніми впливами на розвиток регіонів. Запропоновано використання теоретико-графової моделі для кількісного оцінювання впливів елементів SWOT-матриці (сильні сторони, слабкі сторони, можливості, загрози), в результаті якого визначено пріоритетні можливості, реалізація яких сприятиме регіональному розвиткові: поглиблення інтеграції з $Є С$, поліпшення бізнес-клімату в Україні, стимулювання розвитку малого й середнього бізнесу.

Ключові слова: регіональний розвиток, SWOT-аналіз, теоретико-графова модель, сильні сторони, слабкі сторони, можливості, загрози.
\end{abstract}

Постановка проблеми. На сучасному етапі розвитку України поглиблюються відмінності у рівні конкурентоспроможності регіонів внаслідок посилення глобальних викликів, ризиків і загроз, які в останні роки впливають на економіку країни і іiі регіонів зокрема, розвитку технологій нового покоління, активізації процесу створення об'єднаних територіальних громад, загострення демографічних і соціальних проблем тощо. Тому виникає необхідність здійснення соціально-економічного аналізу, комплексного аналізу порівняльних переваг, викликів та ризиків розвитку регіонів з урахуванням їх специфіки для визначення потреб територій і шляхів розв'язання проблем.

Аналіз останніх досліджень і публікацій. Дослідженню теоретичних підходів до забезпечення регіонального розвитку присвячені численні роботи вітчизняних науковців, а саме: В. Геєця, З. Герасимчук, Т. Заяць, І. Бабець, Д. Буркальцевої, Н. Вавдіюк, А. Гуменюка, М. Кизима, Т. Клебанової, С. Стеценко, А. Сухорукова, В. Ткача, Ю. Харазішвілі, В. Шлемко та інших. Проте їх увага, в переважній більшості, зосереджена на теоретичних аспектах сталого розвитку регіонів та регулюванні соціальноекономічних процесів країни та іï регіонів.

Формулювання цілей статті. Мета даної публікації полягає у визначенні пріоритетних можливостей регіонів, реалізація яких сприятиме розвиткові регіональної системи.

Опис основного матеріалу дослідження. 3 метою виявлення сильних та слабких сторін, можливостей i загроз соціально-економічного розвитку регіонів [1] досліджено регіональні стратегії розвитку Житомирської [2], ІваноФранківської [3], Миколаївської [4], Полтавської [5], Сумської областей [6], які є близькими за основними критеріями (загальна площа території, кількість населення, обсяг валового регіонального продукту, рівень промислового та сільськогосподарського потенціалу, обсяг експортно-імпортних операцій, обсяг річного доходу на 1 особу). Це дає змогу врахувати неоднорідність соціально-економічного розвитку регіонів при здійсненні регіональних зіставлень. Здійснено SWOT-аналіз розвитку їх економічної системи 3 метою виявлення сильних та слабких сторін, можливостей та загроз (таблиця 1).

Таблиця 1

SWOT-аналіз економічної системи аналізованих регіонів

\begin{tabular}{|c|c|}
\hline Сильні сторони (Strengths) & Слабкі сторони (Weakness) \\
\hline $\begin{array}{l}\text { 1. Вигідне географічне розташування. } \\
\text { 2. Значний транзитний потенціал, розвинута мережа } \\
\text { транспортної інфраструктури. } \\
\text { 3. Наявність великої кількості продуктивних } \\
\text { сільськогосподарських земель. }\end{array}$ & $\begin{array}{l}\text { 1. Зношеність існуючої інфраструктури, особливо в } \\
\text { житлово-комунальному та дорожньому господарствах. } \\
\text { 2. Високий рівень фізичного зносу основних фондів у } \\
\text { реальному секторі економіки. }\end{array}$ \\
\hline
\end{tabular}

(C) Джигора О.М., к.е.н., доцент кафедри економічної безпеки, публічного управління та адміністрування Державного університету «Житомирська політехніка», м. Житомир, e-mail: olia.bondarevska@gmail.com 
продовження таблиці 1

\begin{tabular}{|l|}
\hline \multicolumn{3}{|c|}{ Сильні сторони (Strengths) } \\
\hline 4. Сприятливі природно-кліматичні умови для ведення \\
сільського господарства. \\
5. Багатогалузеве сільське господарство. \\
6. Наявність сировинної бази для подальшої переробки \\
сільськогосподарської продукції. \\
7. Високорозвинена харчова промисловість з відомими \\
брендами. \\
8. Наявність значних покладів корисних копалин, \\
відновнювальних та альтернативних джерел енергії, \\
лісових ресурсів. \\
9. Розвинений промисловий потенціал (машинобудівна, \\
хімічна, нафтогазова, добувна, харчова, деревообробна, \\
виробництво будівельних матеріалів). \\
10. Низький рівень екологічного навантаження. \\
11. Потужний природно-рекреаційний потенціал, високі \\
запаси якісних підземних вод, в т.ч. мінеральних. \\
12. Значний історико-культурний потенціал (наявність \\
об’єктів архітектурної, історико-культурної спадщини, \\
наявність місцевих культурно-мистецьких брендів). \\
13. Розвинута мережа навчальних закладів та наукових \\
установ. Високий рівень освіченості населення. \\
14. Кваліфіковані трудові ресурси.
\end{tabular}

Слабкі сторони (Weakness)

3. Високий рівень енерго- та ресурсоємності виробництва, висока залежність від газу.

4. Технологічна відсталість промисловості.

5. Низька інноваційна активність підприємств, слабкі зв'язки з науково-дослідними установами.

6. Недостатня диверсифікація промисловості та ринків збуту.

7. Надмірна експортна орієнтація на ринки країн Митного союзу, в т.ч. Росії.

8. Відсутність регулювання та контролю за внесенням хімікатів у грунти та сівозмінами, що призводить до деградації земель.

9. Невідповідність окремих видів агропродукції стандартам ЄС.

10. Незадовільний стан доріг, особливо в сільській місцевості.

11. Міжрегіональні диспропорції в соціальноекономічному розвитку.

12. Низький рівень використання альтернативних та відновлювальних джерел енергії, впровадження енергоефективних технологій.

13. Відсутність підприємств з переробки та утилізації промислових та твердих побутових відходів.

14. Складна демографічна ситуація.

15. Високий рівень безробіття, особливо в сільській місцевості та серед молоді.

16. Висока трудова міграція населення, в т.ч. відтік інтелектуальних ресурсів, молоді.

17. Невідповідність кваліфікації робітничих кадрів вимогам ринку.

\section{Можливості (Opportunities)}

1. Поглиблення інтеграції з СС (поява нових ринків збуту продукції, зростання експорту).

2. Проведення
$\begin{aligned} & \text { децентралізація } \\ & \text { самостійності громад. }\end{aligned}$

3. Зростання попиту на продовольство на світовому ринку, в т.ч. на свіжу органічну продукцію.

4. Популяризація екологічного способу життя, споживання екологічної продукції, розвиток органічного землеробства.

5. Покращення бізнес-клімату в Україні, стимулювання розвитку малого та середнього бізнесу.

6. Створення сприятливого інвестиційного клімату, в т.ч. за рахунок залучення зовнішніх іноземних інвестицій.

7. Запровадження досягнень міжнародної практики щодо інновацій та технологій.

8. Підвищення ефективності наукового потенціалу.

9. Розвиток IT-галузі.

10. Створення індустріальних парків.

11. Створення потужностей з переробки відходів.

12. Стимулювання енергоефективності (у виробництві, житлово-комунальному господарстві, соціальній сфері).

13. Розвиток альтернативної енергетики.

14. Підвищення транзитного потенціалу, зростання обсягу пасажирських та вантажних перевезень.

15. Розвиток інфраструктури, в т.ч. дорожньої та житловокомунальної.

16. Розвиток туризму, в т.ч. екотуризму (внутрішнього та міжнародного).

17. Зменшення корупції.
1. Політична нестабільність, продовження антитерористичної операції на Сході України

2. Поглиблення економічної кризи в Україні.

3. Повільне впровадження адміністративної реформи, децентралізації влади.

4. Послаблення зовнішньоекономічних відносин 3 країнами Митного Союзу, скорочення інвестицій.

5. Погіршення конкурентоздатності українських товарів через зростання обсягів імпортних товарів 3 країн ЄС.

6. Монополія енергопостачальних структур, зростання цін на енергоносії.

7. Висока залежність від імпортного природного газу.

8. Нестабільність курсу національної валюти, продовження інфляційних процесів.

9. Зменшення внутрішнього товарообороту через низьку купівельну спроможність населення.

10. Посилення розшарування населення за рівнем матеріального добробуту.

11. Зростання трудової міграції.

12. Прискорена депопуляція населення, особливо сільських територій.

\section{Загрози (Threats)}


На його основі для визначення конкурентних переваг, викликів, захищеності та ризиків регіонів запропоновано використовувати інструментарій SWOT-аналізу, що дає змогу побудовати SWOTматрицю й визначити зміст зв'язків між їх елементами, а саме: реалізація сприятливих можливостей забезпечує підтримку сильних сторін та допомагає розв'язати проблеми, пов'язані з наявністю слабких сторін, сильні сторони дозволяють нівелювати загрози, які діють на слабкі сторони системи (рис. 1).

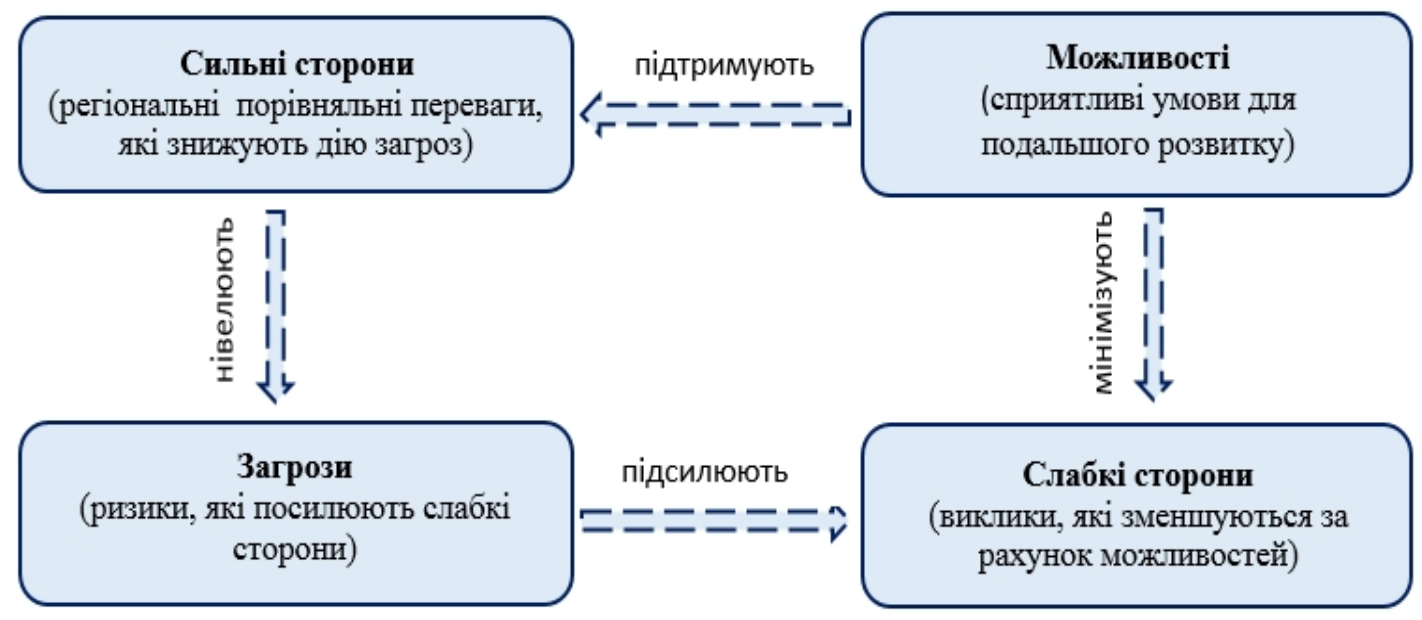

Рис. 1. Взаємозв'язки елементів SWOT-матриці регіонального розвитку

Варіанти кореляцій між внутрішніми чинниками та зовнішніми впливами дозволяють надалі визначити стратегію дій для реалізації можливостей у використанні сильних сторін і зменшення ризиків впливу на слабкі сторони.

3 метою реалізації наступного етапу моделювання взаємодії між елементами SWOT-матриці, кількісного оцінювання впливів одних іiі елементів на інші та визначення пріоритетних можливостей, реалізація яких сприятиме розвиткові регіональної системи, запропоновано використовувати теоретико-графову модель [7,8].

Побудуємо граф $\mathrm{G}$, вершини котрого відповідають елементам SWOT-матриці. Множина вершин цього графа має вигляд

$$
G^{0}=\left\{\alpha_{i}\right\}_{i=1}^{17} \cup\left\{\beta_{j}\right\}_{j=1}^{14} \cup\left\{\gamma_{k}\right\}_{k=1}^{12} \cup\left\{\delta_{l}\right\}_{l=1}^{17}
$$

де $\alpha_{\mathrm{i}}-$ вершини, що відповідають можливостям; сторонам;

$\beta_{\mathrm{j}}$ - вершини, які відповідають сильним

$\gamma_{\mathrm{k}}$ - вершини, що відповідають загрозам;

$\delta_{1}-$ вершини, які відповідають слабким сторонам.

Орієнтовні ребра графа $\mathrm{G}$ відповідають зв'язкам між елементами SWOT-матриці. Ці ребра поділяємо на кілька видів. Ребра $\left(\alpha_{\mathrm{i}} \beta_{\mathrm{j}}\right)$ відповідають зв'язкам між можливостями й сильними сторонами i визначають, які сильні сторони мають найбільшу підтримку через реалізацію сприятливих можливостей. Кожному реброві $\left(\alpha_{\mathrm{i}} \beta_{\mathrm{j}}\right)$ відповідає його вага $\mathrm{f}\left(\alpha_{\mathrm{i}} \beta_{\mathrm{j}}\right)$, що визначає силу відповідного зв'язку. Значення ваги належать до множини $\{1 ; 0,75 ; 0,5$; $0,25\}$. Наявність таких ребер і їх вага визначається матрицею $\mathrm{M}(\alpha, \beta)$, елементами котрої $\epsilon \mathrm{f}\left(\alpha_{\mathrm{i}} \beta_{\mathrm{j}}\right)$. Підграф $\mathrm{G}_{\alpha \beta}$ графа $\mathrm{G}$ на множині вершин $\left\{\alpha_{i}\right\}_{i=1}^{17} \cup\left\{\beta_{j}\right\}_{j=1}^{14}$, що відповідають можливостям та сильним сторонам наведений на рис. 2 .

За умови обмеженості фінансових ресурсів необхідно визначити пріоритети розподілу ресурсів і сконщентрувати їх на тих сильних сторонах, що можуть забезпечити найвищий результат у найкоротший строк та матимуть довготривалий i комплексний вплив на розвиток не лише цієї території, але й сусідніх регіонів.

У результаті побудови підграфа $\mathrm{G} \alpha \beta$ зв'язків між сильними сторонами i можливостями встановлено, що для підвищення рівня розвитку економіки обраних регіонів найбільшу підтримку через реалізацію сприятливих можливостей доцільно 


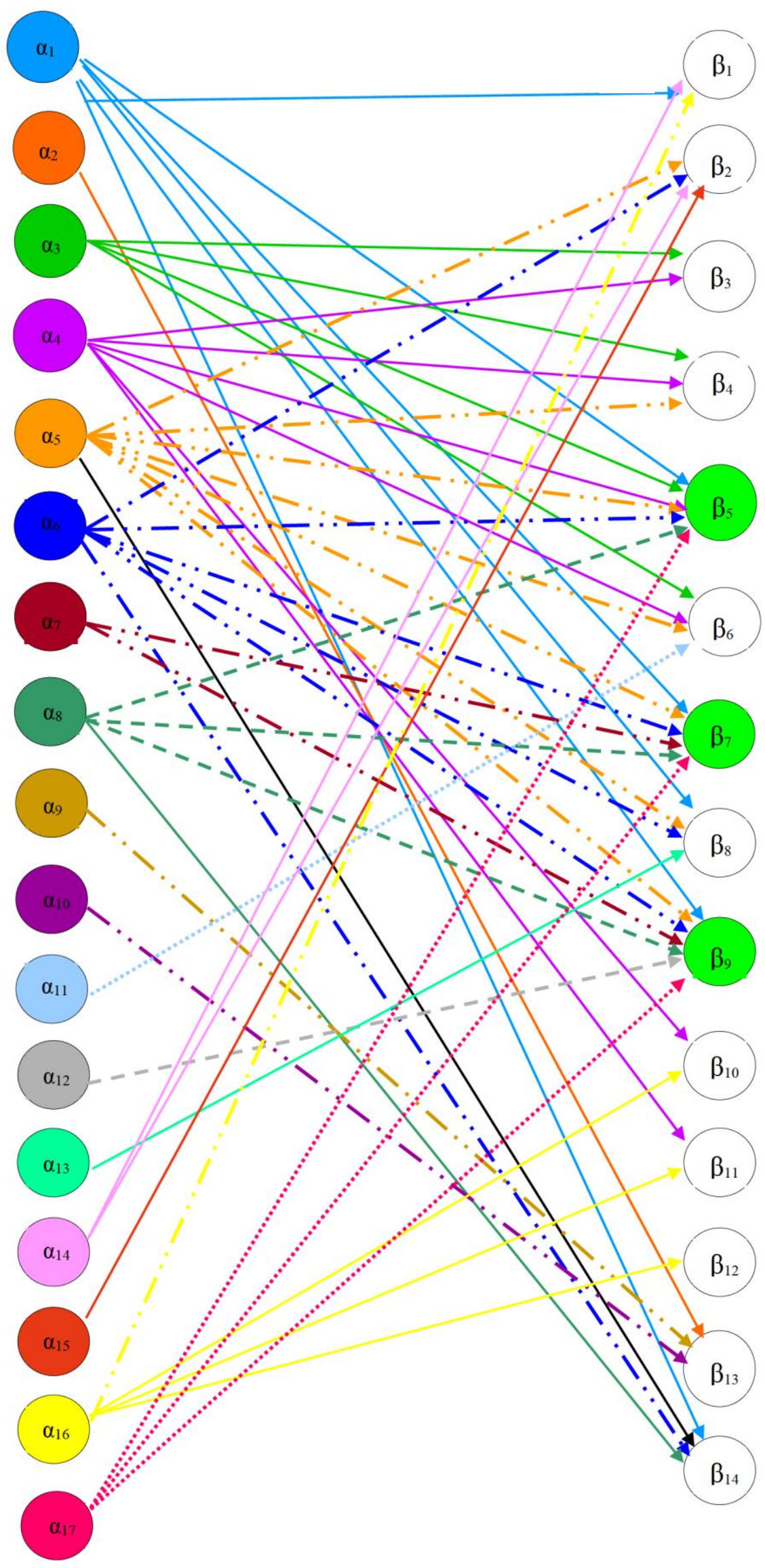

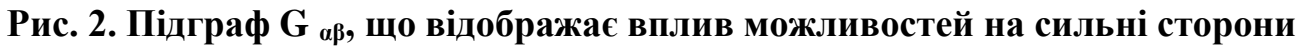


надавати таким їх сильним сторонам: розвитку багатогалузевого сільського

розвиненого промислового господарства, потенціалу, високорозвиненій харчовій промисловості з відомими брендами. Цьому сприятимуть такі можливості: інтеграція України в європейський простір, зростання попиту на продовольство на світовому ринку, в т.ч. на органічну продукцію; поліпшення бізнес-клімату в Україні та стимулювання розвитку малого й середнього бізнесу, створення сприятливого інвестиційного клімату, в т.ч. за рахунок залучення зовнішніх іноземних інвестицій; підвищення ефективності наукового потенціалу; зменшення корупції.

Ребра $\left(\beta_{\mathrm{j}} \gamma_{\mathrm{k}}\right)$ відповідають зв'язкам між сильними сторонами та загрозами і визначають сильні сторони, які дозволяють нівелювати загрози. Кожному реброві $\left(\beta_{\mathrm{j}} \gamma_{\mathrm{k}}\right)$ відповідає його вага $\mathrm{f}\left(\beta_{\mathrm{j}} \gamma_{\mathrm{k}}\right)$, що визначає силу відповідного зв'язку. Значення ваги належать до множини $\{1 ; 0,75 ; 0,5 ; 0,25\}$. Наявність таких ребер та ix вага визначається матрицею $\mathrm{M}(\beta, \gamma)$, елементами якої $€ \mathrm{f}\left(\beta_{\mathrm{j}} \gamma_{\mathrm{k}}\right)$. Підграф $\mathrm{G}_{\beta \gamma}$ графа $\mathrm{G}$ на множині вершин, що відповідають сильним сторонам i загрозам, наведений на рис. 3.

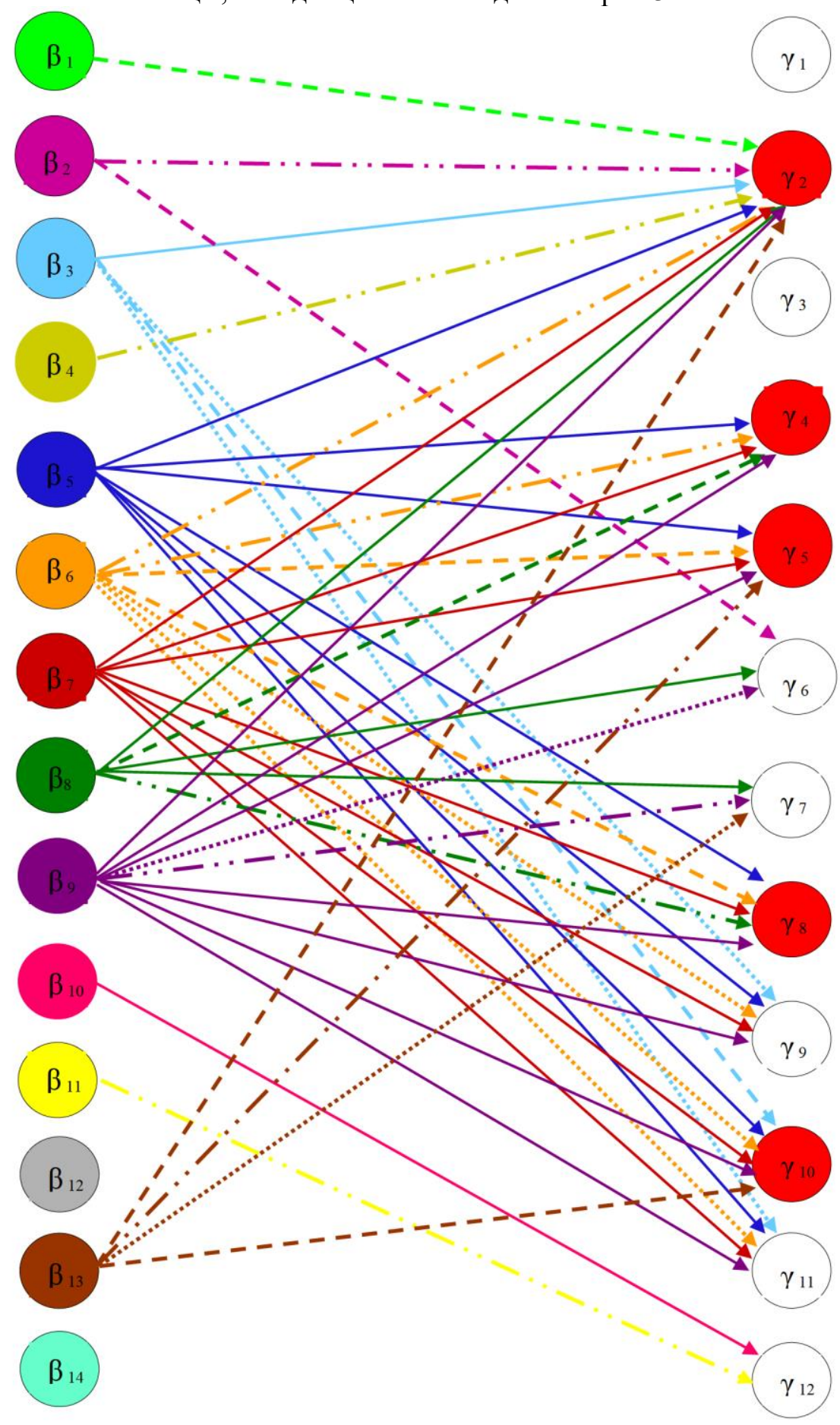

Рис. 3. Підграф $\mathbf{G}_{\beta} \gamma$, що відображає вплив сильних сторін на загрози 
$\mathrm{y}$ результаті побудови підграфа $\mathrm{G}_{\beta \gamma}$ виявлено, що посилення сильних сторін економічної системи аналізованих регіонів найбільше нейтралізуватиме такі загрози: поглиблення економічної кризи в Україні, послаблення зовнішньоекономічних відносин із країнами Митного союзу, скорочення інвестицій, погіршення конкурентоспроможності українських товарів через зростання обсягів імпортних товарів із країн СС, нестабільність курсу національної валюти, збереження інфляційних впливів, посилення розшарування населення за рівнем матеріального добробуту. Серед основних сильних сторін, які компенсують дію загроз, виділено: розвиток багатогалузевого сільського господарства, розвиненого промислового потенціалу, наявність сировинної бази для подальшої переробки сільськогосподарської продукції, високорозвинена харчова промисловість 3 відомими брендами, наявність значних покладів корисних копалин, відновнювальних та альтернативних джерел енергії, лісових ресурсів.

Ребра $\left(\begin{array}{llll}\gamma_{\mathrm{k}} & \delta_{\mathrm{l}}\end{array}\right)$ відповідають зв'язкам між загрозами й слабкими сторонами і визначають найбільш слабкі місця (внутрішні чинники) суб'єкта аналізу під час впливу негативних зовнішніх факторів - загроз, тобто найбільш імовірні ризики при подальшій реалізації планів розвитку регіону (можливі ризики, які слід уникнути або вплив яких мінімізувати через вибір стратегічних рішень). Кожному реброві $\left(\gamma_{\mathrm{k}} \delta_{\mathrm{l}}\right)$ відповідає його вага $\mathrm{f}\left(\gamma_{\mathrm{k}} \delta_{\mathrm{l}}\right)$, що визначає силу відповідного зв'язку. Значення ваги належать до множини $\{1 ; 0,75 ; 0,5 ; 0,25\}$. Наявність таких ребер та їх вага визначаються матрицею $\mathrm{M}(\gamma, \delta)$, елементами котрої $\epsilon \mathrm{f}\left(\gamma_{\mathrm{k}} \delta_{\mathrm{l}}\right)$. Підграф $G_{\gamma \delta}$ графа $G$ на множині вершин, що відповідають загрозам та слабким сторонам, наведений на рис. 4.

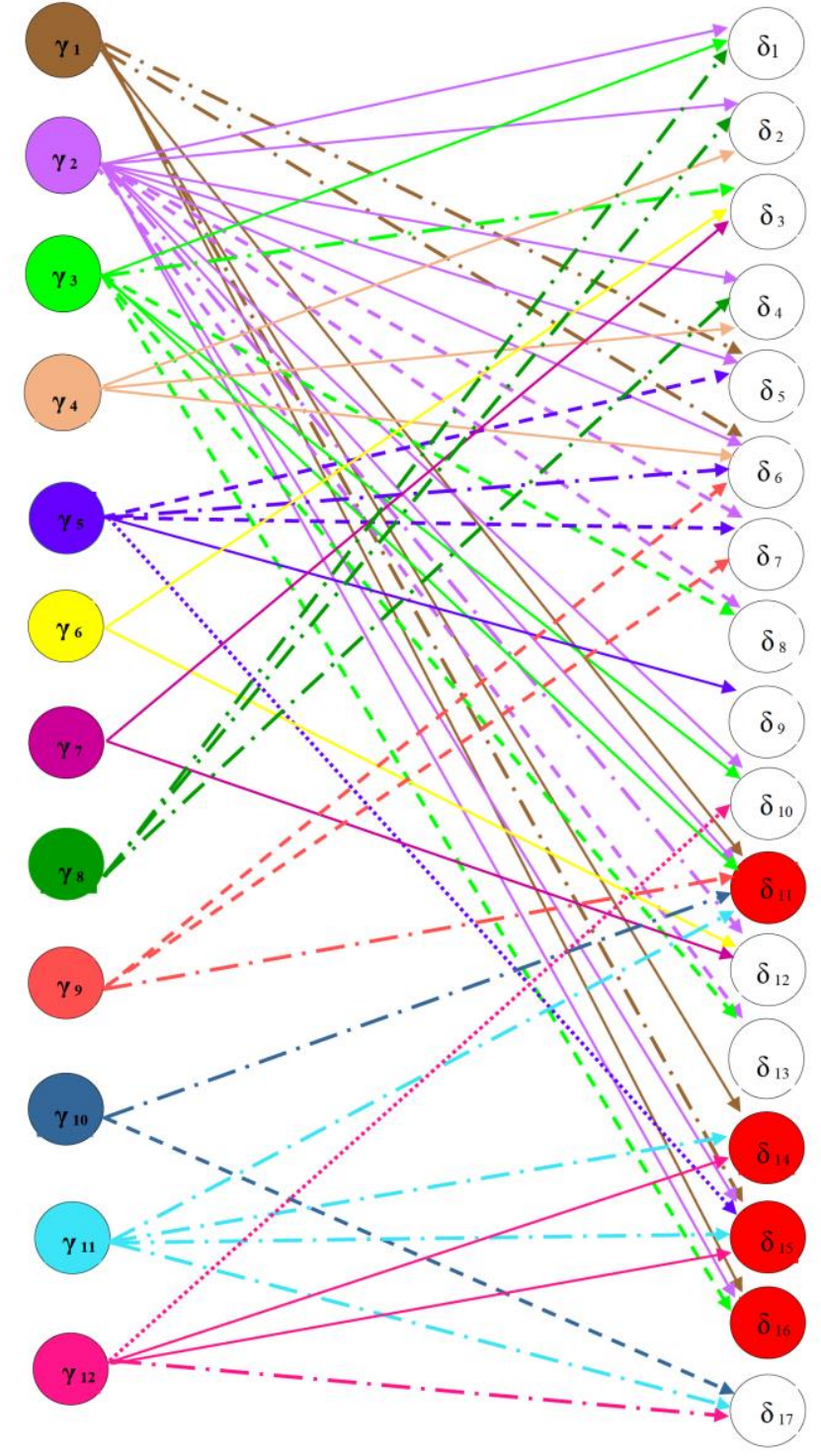

Рис. 4. Підграф $\mathbf{G}_{\gamma \delta}$, що відображає вплив загроз на слабкі сторони 
Підграф $\mathrm{G}_{\gamma \delta}$ визначив найбільш слабкі сторони економічної системи регіонів під впливом негативних зовнішніх факторів (3 високою ймовірністю їх переростання у загрози), серед яких: висока трудова міграція населення (в т.ч. відтік інтелектуальних ресурсів, молоді), міжрегіональні диспропорції в соціальноекономічному розвиткові, складна демографічна ситуація, високий рівень безробіття, особливо в сільській місцевості та серед молоді. Основними загрозами, котрі посилюють слабкі сторони, встановлено політичну нестабільність, продовження Операції об'єднаних сил на Сході України, поглиблення економічної кризи в Україні, прискорену депопуляцію населення (особливо сільських територій), зростання трудової міграції, посилення розшарування населення за рівнем матеріального добробуту.

Ребра $\left(\alpha_{i} \delta_{l}\right)$ відповідають зв'язкам між можливостями та слабкими сторонами і визначають слабкі сторони, які можна усунути за рахунок можливостей. Кожному реброві $\left(\alpha_{i} \delta_{1}\right)$ відповідає його вага $f\left(\alpha_{i} \delta_{1}\right)$, що визначає силу відповідного зв'язку. Значення ваги належать до множини $\{1$; $0,75 ; 0,5 ; 0,25\}$. Наявність таких ребер та їх вага визначаються матрицею $\mathrm{M}(\alpha, \delta)$, елементами котрої $\epsilon \mathrm{f}\left(\alpha_{\mathrm{i}} \delta_{1}\right)$. Підграф $\mathrm{G} \alpha_{\delta}$ графа $\mathrm{G}$ на множині вершин $\left\{\alpha_{i}\right\}_{i=1}^{17} \cup\left\{\delta_{j}\right\}_{j=1}^{17}$, що відповідають можливостям та слабким сторонам, наведений на рис. 5.

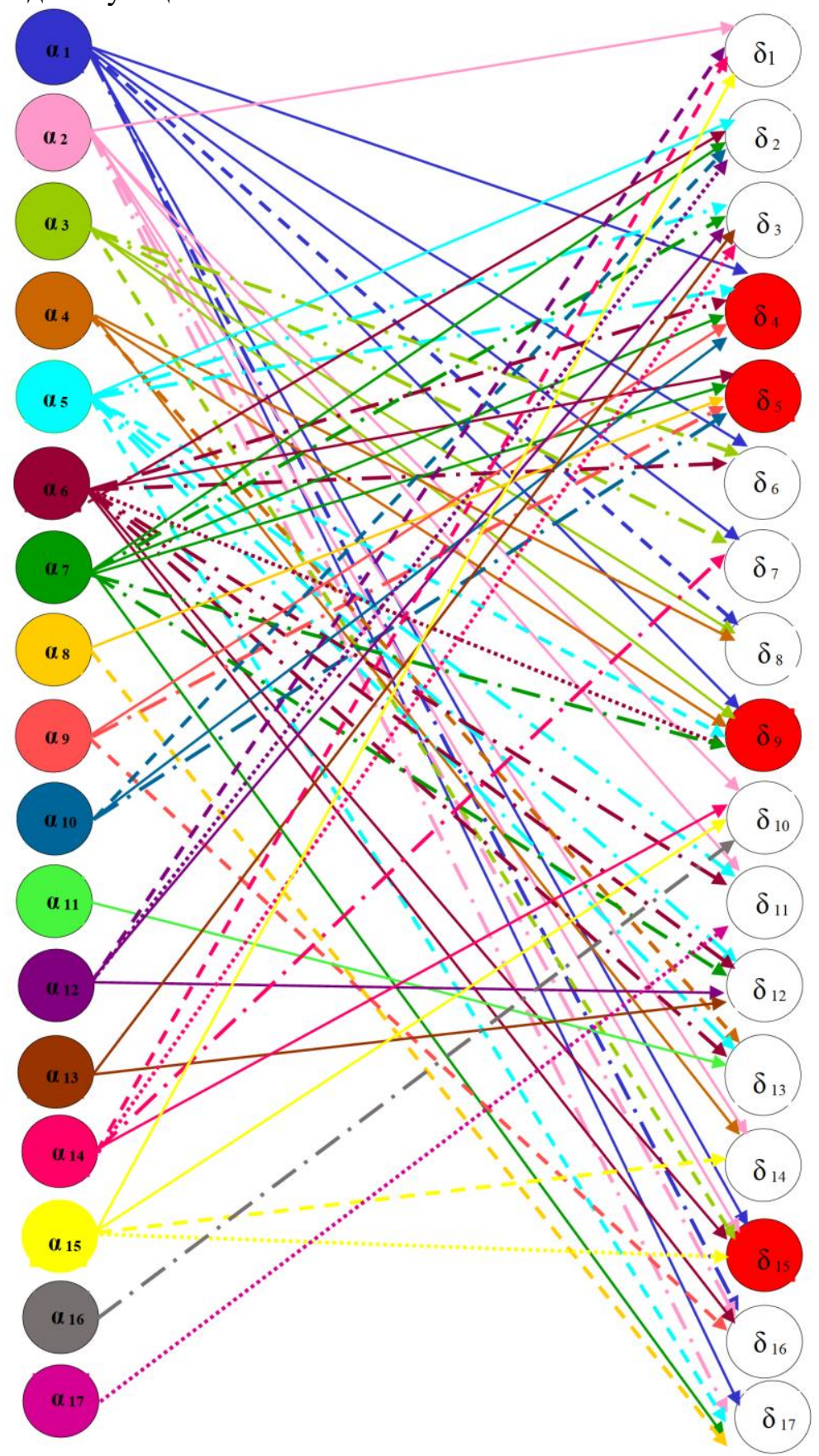

Рис. 5. Підграф G $\alpha$, що відображає вплив можливостей на слабкі сторони 
Побудований підграф $\mathrm{G}_{\alpha \delta}$ дозволив установити можливості, які позитивно впливають на слабкі сторони. За рахунок реалізації можливостей можна мінімізувати такі слабкі сторони: технологічну відсталість промисловості, низьку інноваційну активність підприємств і слабкі зв'язки 3 науково-дослідними установами, високий рівень безробіття (в т.ч. у сільській місцевості та серед молоді), невідповідність окремих видів агропродукції стандартам ЄС. Можливостями, котрі дозволяють зменшити вразливість економічної системи регіону, $\epsilon$ поглиблення інтеграції з СС, поліпшення бізнес-клімату в Україні, стимулювання розвитку малого та середнього бізнесу, створення сприятливого інвестиційного клімату, в т.ч. за рахунок залучення зовнішніх іноземних інвестицій, запровадження досягнень міжнародної практики щодо інновацій і технологій, розвиток IT-галузі, створення індустріальних парків.

Таким чином, за рахунок реалізації можливостей можна мінімізувати такі слабкі сторони регіонального розвитку: технологічну відсталість промисловості, низьку інноваційну активність підприємств i слабкі зв'язки 3 науководослідними установами, високий рівень безробіття (в т.ч. у сільській місцевості та серед молоді), невідповідність окремих видів агропродукції стандартам ЄС.

Включимо до множини ребер графа $\mathrm{G}$ ребpa $\left(\alpha_{i} \gamma_{\mathrm{k}}\right)$, що відповідають зв'язкам між можливостями та загрозами. Сила відповідних зв' язків визначається ваговими коефіцієнтами $\mathrm{f}\left(\alpha_{\mathrm{i}} \gamma_{\mathrm{k}}\right)$, які обчислюються на основі цієї теоретико-графової моделі. Нехай у графі $\mathrm{G}$ існують ребра $\left(\alpha_{\mathrm{i}} \beta_{\mathrm{j}}\right)$ у $\left(\beta_{j} \gamma_{\mathrm{k}}\right)$. Це означає, що реалізація можливості, котра відповідає вершині $\alpha_{i}$, підсилює сильну сторону, яка відповідає вершині $\beta_{\mathrm{j}}$, що зі свого боку сприяє подоланню загрози, котра відповідає вершині $\gamma_{\mathrm{k}}$. Вплив і-тої можливості на подолання k-тої загрози на основі підсилення j-тої сильної сторони оцінюємо величиною $\mathrm{f}\left(\left(\alpha_{\mathrm{i}} \beta_{\mathrm{j}}\right) \mathrm{f}\left(\beta_{\mathrm{j}} \gamma_{\mathrm{k}}\right), \quad\right.$ а загальний вплив відповідної можливості на подолання цієі загрози визначаємо рівністю:

$$
f\left(\alpha_{i} \gamma_{k}\right)=\sum_{j=1}^{14} f\left(\alpha_{i} \beta_{j}\right) f\left(\beta_{j} \gamma_{k}\right)
$$

Це означає, що має місце рівність:

$$
M(\alpha, \gamma)=M(\alpha, \beta) M(\beta, \gamma)
$$

де $\mathrm{M}(\alpha, \gamma)$ - матриця, елементами якої $\mathrm{\epsilon} f\left(\alpha_{\mathrm{i}} \gamma_{\mathrm{k}}\right)$. Включимо до множини ребер графа $G$ ребpa $\left(\alpha_{\mathrm{i}} \delta_{1}\right)$, що відповідають зв'язкам між можливостями та слабкими сторонами. Сила відповідних зв'язків визначається ваговими коефіцієнтами $f\left(\alpha_{i} \delta_{1}\right)$, які обчислюються на основі цієї теоретико-графової моделі. Нехай у графі $G$ існують ребра $\left(\alpha_{\mathrm{i}} \gamma_{\mathrm{k}}\right)$ i $\left(\gamma_{\mathrm{k}} \delta_{1}\right)$. Це означає, що реалізація можливості, відповідної вершині $\alpha_{i}$, сприяє подоланню загрози, котра відповідає вершині $\gamma_{\mathrm{k}}$, яка зі свого боку сприяє подоланню загрози, шо впливає на слабку сторону, котра відповіає вершині $\delta_{1}$. Вплив $i$-тої можливості на $l$-ту слабку сторону на основі подолання $k$-тої загрози оцінюємо величиною $\mathrm{f}\left(\left(\alpha_{\mathrm{i}} \gamma_{\mathrm{k}}\right) \mathrm{f}\left(\gamma_{\mathrm{k}} \delta_{\mathrm{l}}\right)\right.$, яка визначається рівністю:

$$
f\left(\alpha_{i} \delta_{l}\right)=\sum_{j=1}^{12} f\left(\alpha_{i} \gamma_{k}\right) f\left(\gamma_{k} \delta_{l}\right)
$$

Це означає, що має місце рівність:

$$
M^{\prime}(\alpha, \delta)=M(\alpha, \gamma) M(\gamma, \delta)
$$

де $\mathrm{M}^{\prime}(\alpha, \delta)$ - матриця, елементами якої $\epsilon$ $f\left(\alpha_{i} \delta_{1}\right)$.

Загальний вплив можливостей на слабкі сторони відображається матрицею $\mathrm{M}(\alpha, \delta)+\mathrm{M}^{\prime}(\alpha, \delta)$. Підграф $\mathrm{M}_{\alpha, \delta}$, що відображає загальний вплив можливостей на слабкі сторони, наведений на рис. 6 .

Загальні результати моделювання взаємозв'язків елементів економічної системи регіону наведено в таблиці 2 . 


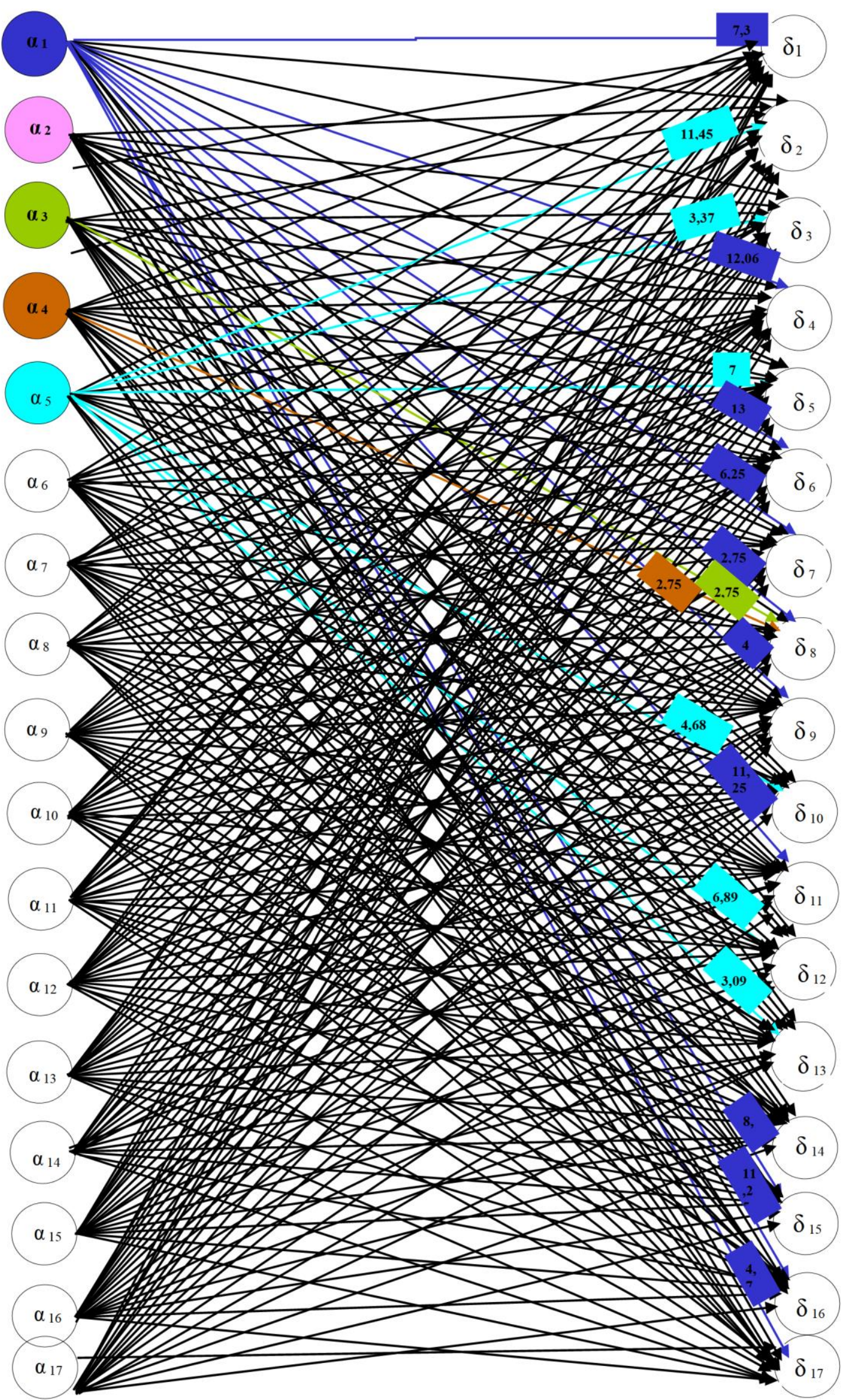

Рис. 6. Підграф $M_{a, \delta}$, що відображає вплив можливостей на слабкі сторони 
Таблиця 2

Результат моделювання взаємозв'язків елементів економічної системи регіону

\begin{tabular}{|c|c|c|}
\hline Підграф & Вплив елементів & Результат моделювання впливу \\
\hline \multirow{3}{*}{$\begin{array}{l}\text { (можливості-сильні } \\
\text { сторони) }\end{array}$} & \multirow{3}{*}{$\begin{array}{l}\text { підтримка сильних сторін } \\
\text { через реалізацію сприятливих } \\
\text { можливостей }\end{array}$} & багатогалузеве сільське господарство \\
\hline & & розвинений промисловий потенціал \\
\hline & & $\begin{array}{l}\text { високорозвинена харчова промисловість } 3 \text { відомими } \\
\text { брендами }\end{array}$ \\
\hline \multirow{7}{*}{$\begin{array}{c}\mathrm{G}_{\beta \gamma} \\
\text { (сильні сторони та } \\
\text { загрози) }\end{array}$} & \multirow{7}{*}{$\begin{array}{l}\text { загрози, що нейтралізуються } \\
\text { дією сильних сторін }\end{array}$} & поглиблення економічної кризи в Україні \\
\hline & & $\begin{array}{l}\text { послаблення зовнішньоекономічних відносин з країнами } \\
\text { Митного Союзу }\end{array}$ \\
\hline & & скорочення інвестицій \\
\hline & & $\begin{array}{l}\text { погіршення конкурентоздатності українських товарів } \\
\text { через зростання обсягів імпортних товарів з країн СС }\end{array}$ \\
\hline & & нестабільність курсу національної валюти \\
\hline & & продовження інфляційних процесів \\
\hline & & $\begin{array}{l}\text { посилення розшарування } \\
\text { матеріального добробуту }\end{array}$ \\
\hline \multirow{4}{*}{$\begin{array}{l}\mathrm{G}_{\gamma \delta} \\
\text { (загрози та слабкі } \\
\text { сторони) }\end{array}$} & \multirow[t]{4}{*}{$\begin{array}{l}\text { слабкі сторони, які } \\
\text { посилюються } \\
\text { загроз }\end{array}$} & $\begin{array}{l}\text { висока трудова міграція населення (в } \quad \text { т.ч. } \\
\text { інтелектудік }\end{array}$ \\
\hline & & $\begin{array}{l}\text { міжрегіональні диспропорції в соціально-економічному } \\
\text { розвитку }\end{array}$ \\
\hline & & складна демографічна ситуація \\
\hline & & $\begin{array}{l}\text { високий рівень безробіття, особливо в сільській } \\
\text { місцевості та серед молоді }\end{array}$ \\
\hline \multirow{4}{*}{$\begin{array}{l}\mathrm{G} \alpha_{\delta} \\
\text { (можливості та слабкі } \\
\text { сторони) }\end{array}$} & \multirow{4}{*}{$\begin{array}{l}\text { слабкі сторони регіонів, які } \\
\text { мінімізуються за рахунок } \\
\text { реалізації можливостей }\end{array}$} & технологічна відсталість промисловості \\
\hline & & $\begin{array}{l}\text { низька інноваційна активність підприємств та слабкі } \\
\text { зв'язки з науково-дослідними установами }\end{array}$ \\
\hline & & $\begin{array}{l}\text { високий рівень безробіття (в т.Ч. в сільській місцевості та } \\
\text { серед молоді) }\end{array}$ \\
\hline & & $\begin{array}{l}\text { невідповідність окремих видів агропродукції стандартам } \\
\text { СС }\end{array}$ \\
\hline \multirow{3}{*}{$\begin{array}{c}\mathrm{M}_{\alpha, \delta} \\
\text { (можливості та слабкі } \\
\text { сторони) }\end{array}$} & \multirow{3}{*}{$\begin{array}{l}\text { можливості, що мають } \\
\text { найбільший } \quad \text { вплив на } \\
\text { подолання слабких сторін }\end{array}$} & поглиблення інтеграції з СС \\
\hline & & покращення бізнес-клімату в Україні \\
\hline & & стимулювання розвитку малого та середнього бізнесу \\
\hline
\end{tabular}


Висновки і перспективи подальших досліджень у даному напрямку. За результатами моделювання та кількісного оцінювання впливів елементів системи визначено пріоритетні можливості, реалізація яких сприятиме регіональному розвиткові: поглиблення інтеграції 3 ЄC, поліпшення бізнес-клімату в Україні, стимулювання розвитку малого й середнього бізнесу. До переваг запропонованого підходу слід віднести те, що він знижує наслідки суб'єктивного оцінювання соціальноекономічного розвитку регіонів, ризиків і загроз, що впливають на динаміку соціальноекономічних процесів, визначають рівень їх економічної безпеки у цілому та за запропонованими складовими. Напрями подальших досліджень у даному напрямі пов'язані з розробленням ефективної програми забезпечення безпеки регіонального розвитку

\section{ПЕРЕЛІК ВИКОРИСТАНИХ ДЖЕРЕЛ}

1. Про затвердження Державної стратегії регіонального розвитку на період до 2020 року, Постанова КМУ від 06.08.2014 № 385. Режим доступу до pecypcy: https://zakon.rada.gov.ua/laws/show/385-2014-\%D0\%BF\#Text

2. Стратегія розвитку Житомирської області на період до 2020 року. Режим доступу до ресурсу: http://economyzt.gov.ua/files/Strateg/strategia2020.pdf

3. Стратегія розвитку Івано-Франківської області на період до 2020 року. Режим доступу до ресурсу: http://www.if.gov.ua/page/19310

4. Стратегія розвитку Миколаївської області на період до 2020 року. Режим доступу до ресурсу: https://economymk.gov.ua/index.php/ua/

5. Стратегія розвитку Полтавської області на період до 2020 року. Режим доступу до ресурсу: https://www.admpl.gov.ua/page/strategiya-rozvitku-poltavskoyi-oblasti-do-2020-roku-0

6. Стратегія регіонального розвитку Сумської області на період до 2020 року Режим доступу до ресурсу: http://sm.gov.ua/ru/oda/6113

7. Зыков А.А. Основы теории графов / А.А. Зыков. - М. : Наука, 1987. -384 с.

8. Оре О. Теория графов. / О. Оре, 2-е издание. Москва: Издательство «Наука»: Главная редакция физикоматематической литературы, 1980. - 315 с.

\section{REFERENCES}

1. Pro zatverdzhennia Derzhavnoi stratehii rehionalnoho rozvytku na period do 2020 roku [On approval of the State Strategy for Regional Development for the period up to 2020] (2020). Resolution of the Cabinet of Ministers of 06.08.2014 № 385. Retrieved from: https://zakon.rada.gov.ua/laws/show/385-2014-\%D0 \% BF \# Text [in Ukrainian]. 2. Stratehiia rozvytku Zhytomyrskoi oblasti na period do 2020 roku [Development strategy of Zhytomyr region for the period up to 2020] (2020). Retrieved from: http://economy-zt.gov.ua/files/Strateg/strategia2020.pdf [in Ukrainian].

3. Stratehiia rozvytku Ivano-Frankivskoi oblasti na period do 2020 roku [Development strategy of Ivano-Frankivsk region for the period up to 2020]. (2020). Retrieved from: http://www.if.gov.ua/page/19310 [in Ukrainian].

4. Stratehiia rozvytku Mykolaivskoi oblasti na period do 2020 roku [Strategy of development of the Nikolaev area for the period till 2020] (2020). Retrieved from: https://economy-mk.gov.ua/index.php/ua [in Ukrainian].

5. Stratehiia rozvytku Poltavskoi oblasti na period do 2020 roku [Development strategy of Poltava region for the period up to 2020] (2020). Retrieved from: https://www.adm-pl.gov.ua/page/strategiya-rozvitku-poltavskoyi-oblasti-do-2020roku-0 [in Ukrainian].

6. Stratehiia rehionalnoho rozvytku Sumskoi oblasti na period do 2020 roku [Strategy of regional development of Sumy region for the period up to 2020] (2020) Retrieved from: http://sm.gov.ua/ru/oda/6113 [in Ukrainian].

7. Zyikov A. Osnovyi teorii grafov [Fundamentals of graph theory] (1987). - M.: Nauka. - $384 \mathrm{~s}$.

8. Ore O. Teoriya grafov [Graph theory] (1980), 2-e izdanie. Moskva: Izdatelstvo «Nauka»: Glavnaya redaktsiya fizikomatematicheskoy literaturyi. $-315 \mathrm{~s}$. 